\title{
MODERN SLAVERY IN THE GLOBAL SUPPLY CHAIN: AN ANALYSIS OF PUBLISHED PREVENTATIVE STATEMENTS AND FRAMEWORKS TO PROTECT BUSINESSES AND INDIVIDUALS
}

Laurel Elise Buck 


\section{ABSTRACT}

Modern slavery generates an estimated $\$ 150$ billion in revenue annually. Derived from the exploited labor 40.3 million victims, this is one of the most profitable illicit industries. Of the estimated 24.9 million slaves institutionalized in forced labor, 16 million are exploited in the private sector. These 16 million are oppressed within corporate supply chains.

This paper addresses the need for a common tool and set of criteria governing organizations' actions. Such a tool and set of criteria are essential in not only combating modern slavery within corporations, but also throughout global supply chain tiers. Application of consistent tools and criteria will move the private sector forward in eradicating modern slavery by ensuring transparent reporting and effective action. Specific research concentrations include analyzing the impacts of modern slavery on parent companies of global supply chains and their increasing liability, making a case for increasing downstream awareness of vulnerabilities to encourage action, and decreasing parent company liability for such crimes. The research deliverable, a modern slavery publication review and analysis, is preceded by a literature review exploring general information on the broader topics of global supply chains, modern slavery, and corporate social responsibility. The final deliverable consists of recommendations for adoption of publications and individual criterionadaptable for all supply chain levels-for corporations to use in implementing, expanding, and improving their modern slavery and transparency initiatives.

The research and analysis detailed provides an instructive introduction for any type of private sector organization wanting to implement, expand, or improve their modern slavery and transparency initiatives. Organizations implementing their first initiatives are recommended to use publications from the Business Rights and Human Resource Centre, Burberry, Tesco, Stronger Together and Marks \& Spencer as the bedrock of their own to ensure comprehensiveness and effectiveness based on industry standards. Organization should be especially mindful to incorporate the vital criteria not included in most publications. These publications and criteria combine to provide a valuable foundation for expanding implementation of such initiatives and will hopefully play a small role in their disentanglement from modern slavery, and ultimately eradication from the private sector altogether.

Embracing corporate social responsibility and going beyond compliance requirements to work toward eradicating modern slavery are difficult positions for companies to commit to without backlash or relentless scrutiny. However, 
the difficulties are met with benefits: companies are likely to increase profits and social acceptance and build brand recognition from adopting proactive approaches to such crimes. Truly, the greatest risk for companies engaging in modern slavery efforts is the risk of inaction; adopting and implementing modern slavery measures benefits public and private stakeholders as well as imprisoned victims yearning for their freedom.

\section{INTRODUCTION}

As of 2017, the crimes of modern slavery generate an estimated $\$ 150$ billion in revenue annually. Derived from the exploited labor and toils of 40.3 million victims, this "silent industry" is one of the most profitable illicit industries-and arguably the most difficult to track. It is estimated that of the 24.9 million modern slaves institutionalized into forced labor, nearly 16 million of these victims are exploited in the private sector. These 16 million people are oppressed within corporate supply chains.

Modern slavery, and the subgroup of forced labor perhaps to the greatest extent, operates on global supply and demand models. Currently, forced labor is supplied by a demand for inexpensive goods, commercialized sex, and inexpensive workers; unfortunately, there is no sign of these demand streams declining. The business model of modern slavery makes these demand streams so egregious and so difficult to combat. Forced labor crimes operate silently in global black markets and under governments' radars, with no country immune to them: "the crime is ... committed right under our noses, and by men and women in suits" (Ochab).

In tandem with the increase in global awareness of the prevalence of modern slavery, there has been an increase in the general public's awareness of and mandate for corporations' social responsibility. As of 2017, 87 percent of consumers supported companies who advocated for social issues consumers themselves champion. Perhaps more tellingly, over 75 percent of survey respondents revealed that they would refuse to do business with a company they believed to be unethical or supported views contrary to their personal moral beliefs (MacCarthy). These statistics support a widespread investment by companies in social responsibility measures, from small businesses to global corporations. Whether undertaken solely to improve public perception or with a dual investment in corporate perception and general social betterment, these investments have spotlighted the threats, liabilities, and risks of global businesses from their extended supply chains. 
Globalization, once a buzzword for expanding companies in the late twentieth century, is now nearly synonymous with general business practices. As free trade agreements accumulated through the late twentieth century and into the new millennium, business of all sizes capitalized on the competitive advantages of myriad national economies and populations to create a previously unequal, booming world economy. Southeast Asian countries quickly became prominent players in the global trading cohort, offering inexpensive labor and production. American and European consumers' purchasing power rose, increasing demand on various economies' metaphorical fruits for the better part of half a century. Global travel for business and pleasure exploded, allowing connections between entrepreneurs across hemispheres and countries like never before. As of 2018, one would be hard-pressed to find a large corporation without some international component to its supply chain.

These international commitments are beneficial in many ways for corporate financials, from improved profitability to reduced operating expenses, but they also come with increased liability that stakeholders often forget and rarely fully consider. The risk of doing business in one country, whether general business risk or legal liability, is increased and expanded for every additional country a corporation touches through business operations. One of those risks, brought to the forefront of public awareness over the past few years and emphasized through increasing business interaction with underdeveloped nations, is that of modern slavery.

This paper addresses the need for a common tool and set of criteria governing organizations' actions. Such a tool and set of criteria are essential in not only combating modern slavery within corporations, but also throughout global supply chain tiers. Specific research concentrations include analyzing the impacts of modern slavery on parent companies of global supply chains and their increasing liability (as international regulations intensify), making a case for increasing downstream awareness of vulnerabilities to encourage action and decreasing parent company liability for such crimes. This study utilizes but is not limited to the following: in-depth research into crime statistics; present and upcoming legal actions and laws; informal interviews with professionals specializing in global supply chains and risk awareness; an analysis of organization publications reporting operation and supply chain transparency and modern slavery initiatives; actions taken to mitigate stated risks and vulnerabilities; and reporting obligations to inform the public of modern slavery publications and occurrences (if applicable). The public statement review and analysis portion of this investigation is accompanied by 
a literature review exploring general statistics and information relating to the broader topics of global supply chains, modern slavery, and corporate social responsibility. This review provides background analysis to substantiate the need for further investigation into the topic and provides a basis for comparing and creating private sector modern slavery and transparency publications. The final deliverable consists of recommendation tables for adoption of public statements and frameworks, as well as individual criteria inclusion and adoption, which are adaptable for all levels of the supply chain. Corporations can utilize these tables to implement, expand, and improve their modern slavery and transparency initiatives and hopefully eliminate modern slavery from their global supply chains.

\section{LITERATURE REVIEW}

To undertake this project, research into various topics of law, liability, global business, and supply chain management was necessary to gain a true understanding of the private sector modern slavery publications' tangible overlaps and connections and to create a foundation for comprehensibly bringing together these diverse ideas. This project required initial research into the background of modern slavery and how the crime is currently relevant for businesses. The research delved into (1) the definition of modern slavery and all subsequent crimes under the broader heading of forced or exploited labor; (2) laws enacted or in play across the globe that hold companies and people accountable for forced labor crimes and what such liability means for global corporations; and (3) the prevalence of these crimes in modern global corporations and the true threat modern slavery poses to the integrity of companies engaging in global business. The literature reveals that the crimes associated with modern slavery are increasing while tracking and prosecution efforts are unable to keep step, meaning people and businesses are facing increasing exposure. The literature also indicates one powerful factor in the increase of these crimes is the expansion of global business and, therefore, global supply chains. Investigations into the workers and businesses within large corporate supply chains have revealed serious exposure and widespread vulnerabilities to modern slavery crimes-exposure parent companies have only just begun to investigate.

This literature review also revealed some of the many prevalent risks of globalized supply chains in the modern business landscape for victims of 
modern slavery and for companies operating across borders. A few of the most impactful insights from the research were about the inherent lack of transparency within globalized companies given differing governmental policies and levels of cooperation, the difficulty of imposing international law, and the general problem of limited resources to investigate lower-tier suppliers in broad geographic operations. This portion of the research calls attention to impediments and legal liabilities that countries face by operating transnationally. Finally, this project exposed the increasing global focus on and demand for corporate social responsibility efforts by companies. Corporate social responsibility programs have been proliferating industries throughout the twenty-first century. As access to information steadily expands, however, so does consumer demand for amplified transparency regarding companies' morals and (un)ethical behavior. Company stocks are increasingly sensitive to consumer and stakeholder perception of goodwill and social advocacy, bringing the problems associated with modern slavery to the forefront of public perception risks. This research delves into the urgency for companies to embrace a strong, public stance in favor of ethical behavior and the demand for businesses, particularly large, powerful corporations, to do more than react to questionable moral situations; stakeholders are now demanding a proactive approach to such social responsibilities and ethical dilemmas.

Ultimately, this project demanded an investigation into the above topics on a broad level in order to ascertain the need for more minute analysis regarding connections of all stated topics and how companies should operate to provide the most desirable environment, legally and socially, for all stakeholders.

Pitting these requirements and recognized obligations against one another and unveiling the parallels, incongruities, and missing synergies within creates a unique setting for corporations to decide how to operate a secure, humane supply chain.

\section{Modern Slavery Law and Corporate Liability}

Laws regarding slavery, its eradication, and revised definitions of crimes like forced labor and trafficking in persons are not new phenomena. Slavery has been isolated by borders and by different governments for centuries. Only recently, however, has the focus of such laws shifted toward broad eradication to investing into businesses' role in reducing and eliminating the crimes of modern slavery with which corporations are so entangled. The United States has passed a selection of legislation targeting modern slavery, but few laws 
emphasize the private sectors' roles and responsibilities. A landmark case for businesses in the United States was decided in California in 2012, requiring "retailers to disclose efforts to eradicate slavery and human trafficking from [their] direct supply chain for tangible goods; definitions; posting on Internet website; contents; injunctive for relief for violation" (California State, Legislature). Largely considered the strictest law in the nation for such disclosures, a retail seller or manufacturer must, at minimum: (1) "engage in verification of product supply chains to evaluate and address risks of ... slavery," which must be conducted by the establishment itself; (2) conduct audits of suppliers and verify compliance with establishment standards via an independent third party; (3) certify that materials incorporated into production comply with modern slavery laws; and (4) maintain internal accountability and training on human trafficking and slavery. This statute is the first of its kind in the United States requiring any sort of compliance of downstream material and parties to parent company standards and legal obligations, opening the doors for increased communication and collaboration between supply chain players to work toward a safer system-and substantially increasing parent company liability. Given the configuration of the judiciary system, however, this statute is not tangible for many global firms in the United States. More than fifty percent of corporations in the U.S. are incorporated in Delaware, demonstrating the breadth of global supply chain parties outside the scope of this statute (California State, Legislature).

Similar to the 2012 California Transparency in Supply Chain Act (CTSCA), the United Kingdom with the UK Modern Slavery Act (UKMSA) of 2015 places pressure on companies that fail to proactively address supply chain risks. Section 54 of the law requires organizations supplying goods or services with a consolidated global turnover of $£ 36$ million per year or more to disclose risks and adopted preventative measures against modern slavery in business operations and associated supply chains. Part Six of the law, "Transparency in Supply Chains," applies to all commercial establishments supplying goods and services, operating some or all of its business in the United Kingdom. The act's scope means UK- and non-UK-based businesses alike are held to a burden of exposure. Though the act does require acknowledgement of supply chain risk, due diligence processes, etc. in relation to sharing proactive strategies, there is little impact to companies and associated supply chain partners should the company fail in any aspect of these requirements. Without similarly strong requirements for successful implementation much of the threat of liability is removed, providing less localized pressure on corporations to follow through 
with this initiative or improve current practices ("Modern Slavery Act 2015").

France has, arguably, the only law with enough judicial and governmental support to compel true obedience in this subject area. The French Corporate Duty of Vigilance Law establishes parent companies' legal responsibility for the ethics of their activities: "activities of the companies they control and activities from their subcontractors and suppliers, with whom they have an established commercial relationship" (European Coalition for Corporate Justice). The first legislation of its kind to place such a high expectation of vigilance on parent companies, this law applies to the largest most established corporations in France, placing the burden of liability on the most powerful conductors of the country's global supply chain connections. Regarding liability, individuals and other companies can hold parent companies accountable for the actions of commercial partners if found in violation of human rights. This law is an important step forward for the international business community to advance protections for at-risk populations and ensure that safeguards are in place to prevent crimes, including modern slavery. By mandating human rights due diligence by powerful corporations, France is publicly addressing a well-known industry liability while promoting action to be taken by both the public and private sectors to combat these crimes. However, this law fails in transparency and initiative reporting requirements. Though human rights due diligence is forefront in the legislation, reporting is not, providing a veil of secrecy and suppression for businesses to hide behind.

The French Corporate Duty of Vigilance Law laid the basis for an up-andcoming federal legislation in Australia passed at the end of 2018. The New South Wales Modern Slavery Act 2018 (NSWMSA) applies a similar burden to parent companies, demonstrating the direction that legislation is moving to marshal the private sector to act in accordance with the worldwide risk it has aggressively underscored (New South Wales Government).

\section{Recognized Areas of Risk and Vulnerability in Global Supply Chains}

16 million victims of modern slavery are exploited within the private sector through corporate supply chains by way of forced labor. As the second most profitable criminal industry, slave labor generates $\$ 150$ billion per year, more than most countries' Gross National Profit. Demand for victims is increasing daily as demand for goods and services surges and world population grows. Companies are more global in operations now than at any era previously. 
creating massive networks of labor and money proving continually difficult to trace and easy to exploit.

\section{THE G20 COUNTRIES LEADING IN AT-RISK PRODUCT CONSUMPTION}

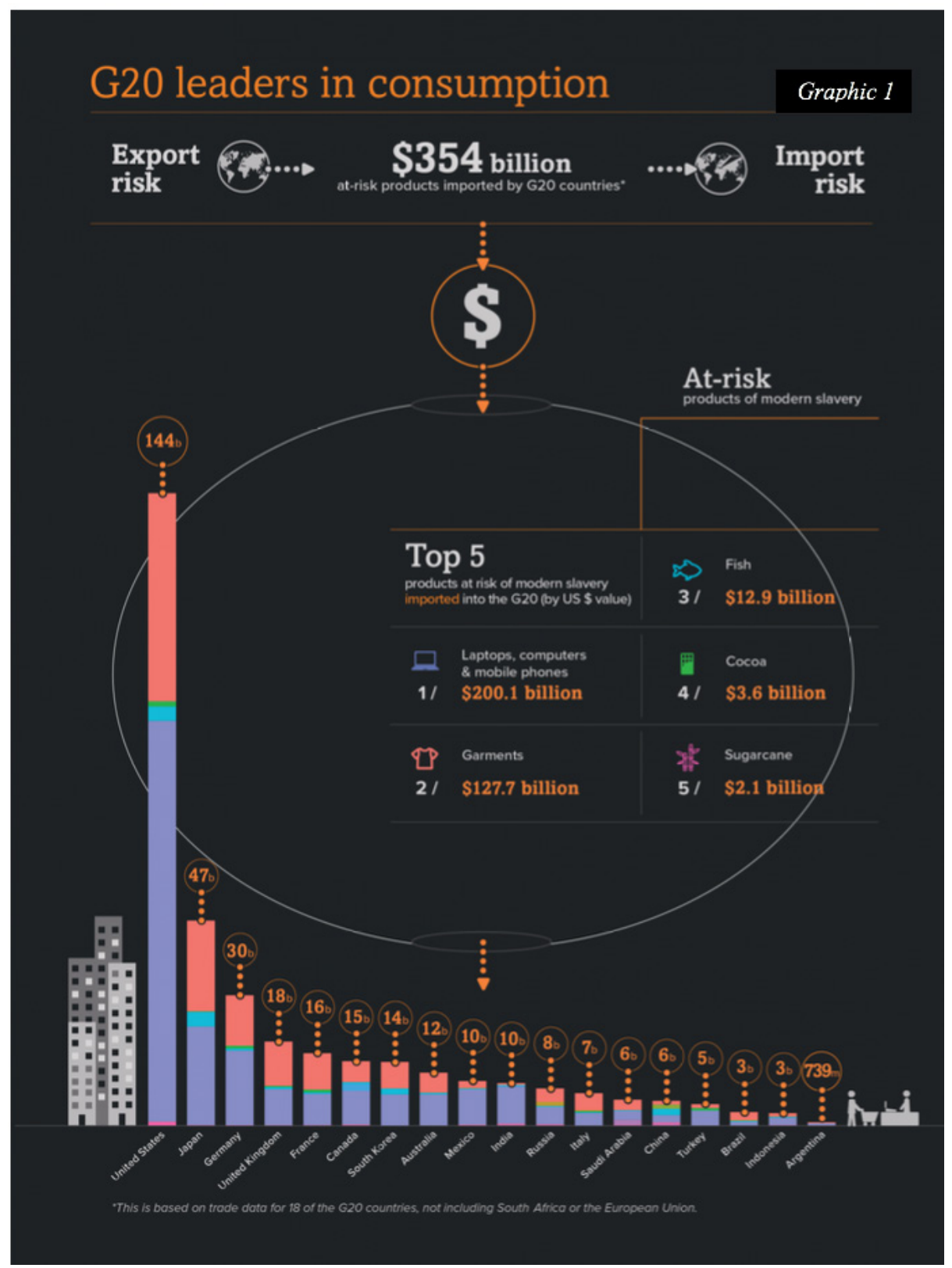


The Walk Free Foundation, a non-profit committed to ending modern slavery, has determined the top five products at risk of modern slavery currently imported into the $\mathrm{G} 20$ leading countries by consumption in their annual Global Slavery Index publication. Represented in the visual "The C2O Countries Leading in At-Risk Product Consumption," world leaders' import consumption of modern slavery risk products totaled \$325 billion in 2018. Risk products derive from industries proven to be most vulnerable to modern slavery crimes, meaning there is a high chance modern slavery was involved at some point in a product's lifecycle. The top five products considered "risky" imported into the $\mathrm{G} 20$ (based on US dollar value) are: laptops, computers, and mobile phones; garments; fish; cocoa; and sugarcane. The apparel and textiles industry are shown as areas of impressive vulnerability ("Understand"). The United States is the leading consumer of imported at-risk product, totaling $\$ 144$ billion, with a majority coming from the highest risk product category: laptops, computers and mobile phones. Japan follows with $\$ 47$ billion in at-risk product consumption, then Germany at $\$ 30$ billion and the United Kingdom at $\$ 18$ billion. For at-risk products, the United States represents approximately 40.6 percent of all G20 consumption ( 2018 Global Slavery Index). Analysis from the 2018 Global Slavery Index concludes the riskiest industries for these crimes share similar traits; all use numerous and/or multi-tiered suppliers, utilize lowcost and/or seasonal labor, are highly competitive, and source commodities from high-risk areas. 


\section{HOW GOVERNMENTS RESPOND TO MODERN SLAVERY}

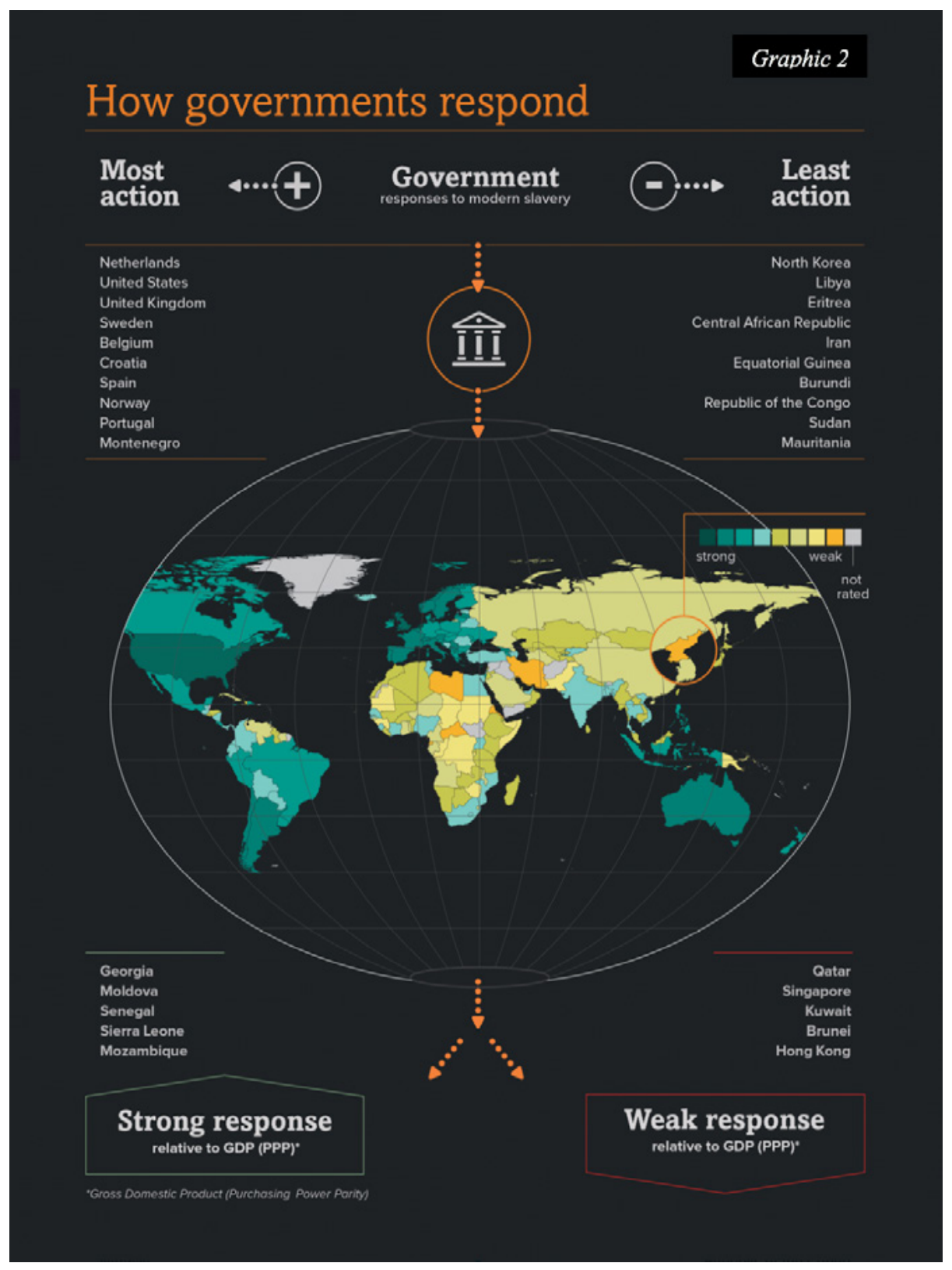


The Global Slavery Index itself, a cross-industry supported publication, offers insight to the portions of the world most vulnerable to crimes of modern slavery. The preceding visual, "How Governments Respond to Modern Slavery," portrays the degree of action governments are understood to take in response to modern slavery. $\mathrm{C} 20$ nations such as the United States, the United Kingdom, and the European Union bloc constitute many of the most active nations in combatting these crimes. Several of the most vulnerable nations, including the Republic of Congo, Eritrea, North Korea, and Burundi, were found to take the least action. Some governments considered highly vulnerable were also subcategorized as having strong responses relative to GDP; Senegal, Sierra Leone, and Mozambique are a few of the high-risk nations emerging as category leaders. Specifically, for $\mathrm{G} 20$ countries, the index calls attention to those taking action to stop slavery in supply chains and those which are not. Only sevenBrazil, China, France, Germany, Italy, United Kingdom, and the United Statesproved proactive. The conclusion of the report: consumers must do more (2018 Global Slavery Index).

There are myriad organizations, from non-profits to industry coalitions, contributing to research about risks and vulnerabilities in global supply chains and raising private sector awareness. The International Labour Organization (ILO), the Mekong Club, and KnowtheChain are three that provide manifold free resources, easily accessible information, and research statistics to consumers and global businesses and contribute to international publications, including the Global Slavery Index, used by governments to recognize and combat modern slavery. These three organizations specifically focus their information and public platforms on addressing how businesses can identify, address, and prevent modern slavery within their global operations.

Research conducted by the ILO supports the research presented in the Global Slavery Index. Though modern slavery occurs in every region of the world, it is most prevalent in Africa (7.6 per 1,000 persons), followed by Asia (6.1 per 1,000), and Europe and Central Asia (3.9 per 1,000). When looking specifically at forced labor, Asia boasts the highest prevalence (4 per 1,000) followed by Europe and Central Asia (3.6 per 1,000) and Africa (2.8 per 1,000). The regions with highest prevalence of modern slavery correspond to the Global Slavery Index countries cited as taking the least preventative action and of the highest risk. The final conclusion drawn from the report emphasizes the importance of international cooperation in addressing modern slavery. Most forced labor is found in the private sector, the report concludes, only further accentuating the importance of partnering with and within the business 
community to "eradicate forced labor in supply chains and the private economy more broadly" (International Labour Office).

As a tangible example, the ILO, regarding the retail industry, characterizes the textiles, clothing, leather and footwear sector as "geographically dispersed production and rapid market-driven changes," providing millions of work opportunities; it is also characterized by "high volatility, low predictability, generally low profit margins," a high proportion of subcontracting, laborintensive work and trends toward faster, more flexible production and everlower prices ("Global Estimates of Modern Slavery"). These characteristics match closely with those described as generally describing high-risk industries.

The Mekong Club is a nonprofit operating with a particular interest in recruiting the private sector for help eradicating modern slavery. A supplement to efforts made by world governments, NGOs, and the United Nations, which only collectively help $0.2 \%$ of victims each year, Mekong Club interacts directly with private ownership to achieve change. The Mekong Club describes seven of every ten modern slaves as "directly related to the private sector," from the clothes consumers purchase to the food they eat. Citing additional data from the Global Slavery Index, the Mekong Club draws a direct connection between slavery and supply chains, arguing that businesses cannot plead innocent or ignorant to these problems anymore (Ochab).

The Mekong Club provides tools for companies in or connected with particularly high-risk industries to assess supply chain vulnerability and risk and possible approaches to risk mitigation. One of the four industries is retailers. The Mekong Club identifies apparel's extensive supply chains, manufacturing channels, and heavy presence in developing nations as key hardships companies can encounter when managing such risk. The Mekong Club is pursuing standardization and information sharing across the industry, from risk assessment tools to auditing approaches, to better secure the operations of such companies ("Our Strategy").

Combining the powerful private sector forces of investors and companies, KnowTheChain is a partnership utilizing benchmarking to identify and share best practices to adopt standards protecting workers' well-being. Collaborative efforts have enabled a push for changes in working conditions in global supply chains and a recognized commitment to ending global forced labor. KnowTheChain's research confirms that outsourcing and offshoring production often leads to an environment of uncertainty around a company's supply chain network, creating situations ripe for exploitation. The organization directly describes this lack of knowledge and certainty in global supply chains as a 
business risk, opening parent companies to "severe labor abuses through their direct and indirect suppliers" (Ochab). As supporting evidence, KnowTheChain outlines the laws and regulations in the US and UK, now requiring companies to disclose their networks risks and efforts at mitigation and/or eradication, and the fact that worldwide such transparency movements are gaining momentum. Shifting the narrative to a more business-centric approach, the organization outlines the mounting pressure "from investors, consumers, media and governments to maintain responsible and transparent supply chains" as a protection not only to the victims of slavery, but to the legal, financial and reputational positions of companies. Encouraging active participation in new legislation and embracing transparent supply chain management, KnowTheChain has concluded, protects business interests from legal and financial liability, loss of brand reputation and workers' rights violations (Ochab).

KnowTheChain is yet another organization focusing aid to specifically high-risk industries, using their research to compile resource and action guides published in 2017. The resource provides companies operating in these industries or with network connections to them guidance on addressing supply chain vulnerabilities to forced labor. Created as a complement to the organization's first benchmarking initiatives, the resources emphasize areas found to be especially weak in transparency processes. Pertinently, the benchmarks highlight widespread lack of knowledge of removed supply chain partners and their ethical practices. KnowTheChain's research concludes that companies overwhelmingly focus efforts on the first tiers of their supply chains with few working to understand the same risks associated with deeper tiers (Ochab).

\section{Demand for Corporate Social Responsibility by Corporations}

Corporate social responsibility (CSR), also referred to as corporate citizenship, is the self-regulating practice of companies holding themselves socially accountable to all stakeholders. Companies embracing CSR are conscious of the business' impact on all societal aspects, including economic, environmental, and social sectors. Popularity in adopting CSR-focused business models has risen steadily in the twenty-first century, driven by a correlated increase in consumer demand for socially accountable companies (Carroll).

In a New York magazine article published in 1970, Milton Friedman, famed economist, states his professional opinion that businesses investing in CSR programs "'reveal a suicidal impulse'" (Chong). Regardless of Friedman's 
warning, over the past forty-odd years, many successful, profitable businesses have made CSR programs their top priorities, even going so far as to use such programs as competitive advantages. This shift in economic theory has no doubt been underscored by the increasing number of millennials and Generation $Z$ members rapidly gaining purchasing power and economic influence. Millennials are willing to "make personal sacrifices to make an impact on issues they care about," states a 2015 Cone Communications Millennial CSR study. "More than 9-in-10 millennials would switch brands to one associated with a cause," demonstrating stark contrast between millennials and generations prior regarding brand loyalties. Brand loyalty is now often discussed in tandem with social causes, political trysts between CEOs and politicians, and an ever-increasing emphasis on corporations behaving "better." As of early 2017. millennials accounted for 80 million consumers and an impressive "one trillion dollars of total consumer spending in the United States," easily explaining why companies have expanded their concentrations so drastically to accommodate millennials' generally cause-focused, impact-driven motivations (Chong).

In a similar study about purchasing trends and CSR programs conducted by Forbes, James Epstein-Reeves found "more than $88 \%$ of consumers think companies should try to achieve their business goals while improving society and the environment," and perhaps even more telling, " $83 \%$ of employees would seriously consider leaving their job if their employer used child labor in sweatshop factories" (Epstein-Reeves). In reaction to these opinions, it has become commonplace for companies to offer additional personal days for volunteering; to take the lead in combatting child labor and low wages in developing countries; to adopt green initiatives in the workplace; and to develop statements of competency and preventative measures for combatting crime in increasingly-global supply chains. However, how many of these programs, born from the apparently ardent desire of employees and stakeholders, are followed through on? How many go beyond informational conception and deliver results farther down the supply chain? How beneficial are these initiatives to companies, really, when CSR programs do not focus on the company's bottom line nor maximizing shareholder return?

Many companies, since the CSR movement gained traction, have come under fire for disrupting the traditional role of business. Corporations have been accused of overstepping and ignoring their most fundamental deliverable: shareholder return. Tom Borelli, guest contributor to Forbes, attacks Unilever CEO Paul Polman as "a poster child of a CEO gone wrong," claiming that Polman's emphasis on social policies are "self-serving goals" that have taken 
priority over shareholders. Polman, since becoming CEO in 2009, champions his personal mission as galvanizing the company "to be an effective force for good," which Borelli suggests has utterly distracted him from Unilever's core business (Borelli).

A similar analysis piece painting CSR programs as villains was introduced in The Telegraph following Volkswagen's corporate wrongdoing scandal of 2015. Matthew Lynn describes CSR as "a racket - and a dangerous one. It allows companies to parade their virtue, and look good, while internal standards are allowed to slip." During the same year, Volkswagen was touted as a global leader in CSR, even being ranked the eleventh highest in the world for company's social responsibility work. According to Lynn's examination it was the external focus on social activism and leadership that allowed such internal chaos to run rampant. Lynn, like Borelli, uses this example of extreme wrongdoing to call attention to the historical responsibility of business: "to make... products, to honour their contracts and to pay their staff and suppliers on time. Everything else is just a smokescreen" (Lynn).

What, then, are the recognized benefits for companies in adopting such radical CSR initiatives? Even with the expanding breadth of consumers championing social responsibility as a necessity in choosing brands, such scandals call into question the true ethical standards of companies even as they espouse extensive, liberal investments in the world's most pressing social crises. In reality, the blame of CSR programs on internal misconduct has no real causational proof. In a Harvard Business Review (HBR) study, researchers V. Rangan, Lisa Chase, and Sohel Karim conclude that the truly problematic instances of CSR interfering with business deliverables stems not from the programs themselves but from the programs' focuses and breadths being unsustainable. As CSR grows in importance for those with purchasing power so does the pressure to transform CSR into its own business discipline, diverting such programs from their original goal(s): "to align a company's social and environmental activities with its business purpose and values." HBR's study investigates why firms need to refocus on this original goal for the betterment of both CSR programs and the companies themselves, advocating for the bringing of discipline to CSR strategies.

In surveying 142 managers, alumni from Harvard Business School's CSR executive education program, HBR researchers found "remarkably consistent" results. Despite the commonly held motivation behind CSR as pursuing "shared value' - creating economic value in ways that also create value to society," many of these programs' true quests are generally far broader, running the 
gamut from "philanthropy to environmental sustainability to the active pursuit of shared value." To maximize such programs' positive impacts, the research showed that companies must develop clear, well-managed, disciplined, coherent strategies ("The Truth About CSR"). The first step in such development, $\mathrm{HBR}$ researchers suggest, is to align and bring coherence to programs within a business theater; that is, to coordinate efforts, deliverables and benefits within a business' supplier and partner landscape. For example, emphasizing a program that impacts all supply chain partners and can be mutually beneficial between partners has a much higher probability of bringing cost savings and tangible CSR deliverables than a strategy removed from the strengths and weaknesses of the landscape(s). The most impactful shared value CSR programs align with the business' purpose, important stakeholders' values, and community needs wherein the company operates: in tightening CSR focus and engagement, companies will benefit and bring value to their shareholders while increasing value for all stakeholders of the operation ("The Truth about CSR").

\section{Summary}

This literature review investigated three topics: Modern Slavery Law and Corporate Liability, Recognized Areas of Risk and Vulnerability in Global Supply Chains, and Demand for Corporate Social Responsibility by Corporations. Research about modern slavery law and its connection to corporate liability revealed legislation aimed at preventing modern slavery crimes is increasingly popular worldwide, with immense impact to corporations hallmarking recent bills such as the UKMSA and the NSWMSA, laying the groundwork for other countries and economic areas to place the liability of such crimes squarely on the premier, dominating corporations of compromised global supply chains. Investigation into the areas of recognized risk and vulnerability in global supply chains supported the emphasis of these legislative pieces on blaming parent corporations: the most vulnerable portions of global supply chains proved almost exclusively far-removed from the operations of parent companies yet integral to the entire operation, almost authorizing parent corporations to operate in a "don't ask, don't tell" manner while their actions spur the continuing enslavement of persons in less economically-fortunate, under-developed countries. Finally, in exploring the trend of increasing consumer demand for corporations to invest in corporate social responsibility it became obvious that heightening demand is only encouraged by millennials and Generation Z gaining purchasing power; despite some positions that 
CSR negatively distracts from the historical mission of corporations to solely maximize shareholder return, it is progressively more beneficial for companies to create CSR initiatives designed to bring true social impact to the entire operational landscape and thus shared value to all supply chain players, meeting the needs and demands of shareholders while improving impacted communities. As CSR gains traction the phrase "social impact" is becoming the new standard for companies invested in their positive corporate citizenship. In describing the differences between general CSR programs and the new branding shift of social impact, Liba Rubenstein, senior vice president of social impact at 21st Century Fox, explains: "this ... reflects a growing consensus that the key driver for a company's pro-social program should be not some generic standard of responsibility or as penance for perceived negative effects, but rather unique, measurable, positive impact-human, environmental, societal, and financial" (McPherson).

The above explanations combine to highlight the undeniable need for global corporations to develop impactful, shareholder-friendly, measurable corporate citizenship initiatives to combat modern slavery crimes within extended supply chains; such initiatives are necessary not only for corporations' growth and sustainability, but for the betterment of the increasingly globalized world.

\section{RESEARCH METHODOLOGY}

This research project was achieved through combining multiple avenues of analysis and data into a comprehensive, attainable deliverable. By incorporating data and previous analysis from a variety of sources, including research institutions; non-profit and non-governmental organizations; companies and corporations spanning numerous industries; and news sources; the deliverable created in this project is broad enough to be useful to a variety of handlers while incorporating a range of information comprehensive enough to enable impactful consumption. Detailed background research laid the foundation for the project; it is imperative to understand the current plight of modern slavery as it applies to the private sector as well as what initiatives are already underway to counteract this global tragedy in order to grasp how the private sector's actions must improve. Initial research was drawn from subject matter experts, either through personal discussions or online resources via organizations, to conclude what the state of modern slavery worldwide is today. This research concentrated on countries most involved in global companies' supply chains as well as countries with historically high modern slavery rates: the United States, 
the European Union, and Australia, along with underdeveloped nations in Southeast Asia and resource-rich nations in Africa.

Following this initial investigation, the topic of research shifted toward industry, using the data accumulated on modern slavery to understand how, where, and when global supply chains are most impacted and what the incentives are for companies to address these crimes. In understanding how companies have either chosen or been forced to respond to modern slavery, it became apparent that there are also companies going above and beyond legal necessities to create comprehensive, tangible plans to eradicate modern slavery from their practices and those of their supply chain partners. As such, the research went on to include a fourth component: compilation and analysis of published anti-modern slavery frameworks and deliverables by companies, non-profits, and government organizations with the intent of determining what made these plans successful or not and how other companies lacking deliverables can utilize these tools to create unique frameworks to eradicate modern slavery crimes in their own supply chains. This process allowed for a pre-tested field from which to compile best practices and missed opportunities for other industries to capitalize on for global benefit. In all, the research accomplished for this project enabled discovery of several factors that should be considered for optimal modern slavery deliverables, important factors that should be included in deliverables that are not often adopted, and what key indicators must be further developed for high-performing, comprehensive publications.

\section{DELIVERABLE}

"A company's pro-social program should be not some generic standard of responsibility... but rather unique, measurable, positive impact-human, environmental, societal and financial." (McPherson)

Following the 2012 California Transparency in Supply Chain Act (CTSCA) and the $2015 \mathrm{UK}$, corporations falling under either respective legislations are required to produce and publish yearly statements regarding their work - or lack thereof - to eradicate and prevent modern slavery within organization operations. Governments overseeing both acts published certain frameworks and guides for companies to use in meeting the legislative requirements; nonprofit organizations, governments of other global nations, and corporations themselves followed suit. As such, there are as variety of resources available from which to learn how to eradicate and prevent modern slavery from any 
type of organization; however, there are far fewer resources detailing which frameworks and regulatory guides are most comprehensive and/or successful in goal completion. This data gap ultimately directed the following research deliverable. Following background research, detailed in the above literature review, twenty prominent contributors of modern slavery frameworks, statements of compliance, and toolkits from over forty reviewed publications were selected for a more focused scope of analysis. These contributions were used to compose an analysis of publication details and criteria inclusion; where information and suggestions overlapped and where they did not; which publications appear most informational and comprehensive; and what, if any, key preventative criteria were lacking or altogether missing that should be included for optimal results.

The entirety of this comparison is located in Appendix 1; the following outline will detail the most imperative information found from the comparison, any key points of reference or examples, and any necessary explanation of methodology used.

\section{Organization Types Included}

Publications in this analysis include frameworks and statements from non governmental and non-profit organizations, for-profit companies, government entities, membership societies, and public education institutions to deliver the most inclusive comparison possible amongst the different deliverables publicly available. Each organization type is propelled by different motivations for publishing modern slavery and transparency initiatives, in turn determining overall content concentrations. For example, the for-profit companies included in the comparison published modern slavery statements in response to either the CTSCA or the UKMSA. Whether responding to requirements for one or both, differentiated publications showed inclusions of information, requirements or suggestions of internal and external stakeholders, etc. Likewise, government entities published documents displaying similar motivations as for-profit companies with a generally lower detail level, allowing a broader spread of organizations to utilize their publications. Membership societies were motivated by interests pertinent to a member majority, such as a specific industry of forprofit companies or organizations striving to meet similar legislative guidelines, thus tailoring their documents to address those specific requirements. Nongovernmental and non-profit organizations and public education institutions appeared least confined to any particular group of stakeholders, often resulting 
in more inclusive documents; however, this also allowed more freedom to personally tailor publications and determine necessary information to include, making the suggestions less regulated and possibly less comprehensive. Each organization included is placed into one of the mentioned categories to invoke understanding of these motivations throughout the criteria analysis.

\section{Organizations' Countries of Origin}

Similarly, to the inclusion of organization type, research that indicated organization origin influences motivations and/or criteria. Of all analyzed documents there were three countries of origin: the United Kingdom, the United States of America, and Australia. This demonstrates a correlation between the organizations producing proactive modern slavery actions and deliverables and countries who have passed legislation to combat modern slavery. The inclusion of country of origin allows for another layer of analysis: which organizations are producing statements and including certain criteria because they want to versus because of legal obligation.

\section{Analysis Criteria}

The goal for these criteria was to be as comprehensive as possible of the requirements and suggestions laid out by the twenty included organization publications, regardless of the duplicity of specific criteria. After reading through over forty frameworks and modern slavery statements, one in particular encompassed the majority of criteria included in all other publications reviewed: the Business and Human Rights Resource Centre Modern Slavery report. The conditions included within this toolkit formed the basis of my criteria, after which any prominent, missing conditions from other utilized publications were incorporated to create a comprehensive analysis.

In total, 127 criteria were identified for inclusion. The majority were standalone conditions; some include varying degrees of compliance for which an organization's document would not call for more than one degree to be completed. As an example, one criterion included is "Require external stakeholders' compliance with modern slavery eradication efforts." From this criterion branch ten sub-criteria, ranging from "Encourage compliance with..." to "Require compliance with..." None of the documents included "encouraged" compliance with one internal set of expectations while also "requiring" compliance; as such, no organization is able to meet all 127 included. 
All criteria are separated into three broad categories: For Organization (Internal Operations); For Supply Chain Partners (External Operations); and For Public Outreach (Publications, etc.). Some of the criteria falling in each category may be worded similarly, however the implication of the requirement(s) differentiates based on which category the criteria belong in. For example, requiring compliance with an organization's Code of Conduct is a different requirement under the For Organization category than For Supply Chain Partners. Each provides a different view of modern slavery eradication.

\section{Spreadsheet Description}

The spreadsheet created as part of this analysis was designed to be easily accessible for outside organizations to use for internal purposes, while incorporating all information in an easily comprehendible, visual format. The horizontal axis details information about the source of the included information: what organization published the document, type of organization, and headquarter location(s). The vertical axis details the criteria utilized, separated into the previously mentioned three broad categories and further subcategorized into independent criteria and sub-criteria (additional level(s) of detail pertaining to the independent criteria's inclusion). An " $X$ " represents the criteria's presence in a document; a line-filled box represents a criteria's lack of inclusion. The full analysis spreadsheet can be accessed in Appendix 7. 
Summary of Findings

\section{TOTAL CRITERIA INCLUDED BY GEOGRAPHIC REGION}

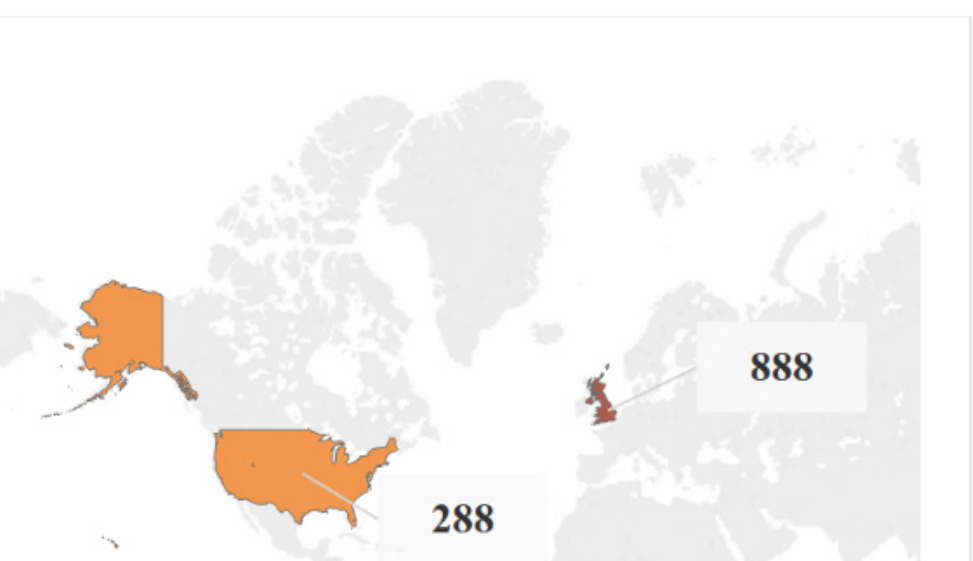

44

Map based on Longitude (generated) and Latitude (generated). Color shows sum of Number of Records. Details are shown for Location.

Number of Records

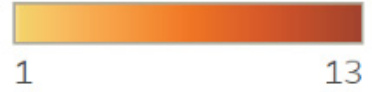

Graphic 4 
From the most macro level of analysis drawn from Appendix 7 , it is evident which country's organizations provide the most met criteria in publications: the United Kingdom. Thirteen were analyzed from countries headquartered in the United Kingdom with a total count of 888 included criteria (an average of 68.3 criteria per publication). The United States' organizations trail considerably, delivering an average of 48 criteria for six analyzed publications. Australia, finally, represented 44 criteria with one organization.

The United Kingdom and United States are generally considered the global leaders in modern slavery act legislation, with the 2015 UKMSA being "the gold standard in the fight against contemporary slavery" (Needle). The over ten-point spread in average criteria incorporation, however, paints a different image of how similar these legislative initiatives are actually. The UKMSA's broader required compliance scope and more detailed reporting obligations have seemingly produced a much more penetrating measure for organization transparency and preventative measures than the CTSCA. Indeed, the number of United Kingdom organizations and subsequent criteria included in the Appendix 1 analysis advocates a strong position for the concrete, beneficial deliverables that can follow such preventative legislative measures. The UKMSA should serve as an example of successful modern slavery legislation for other countries and organizations appealing to increase transparency and preventative measures.

Investigating more deeply into the criteria measures included in Appendix 7 , this analysis can also be utilized for further inspection of individual organization criteria and preventative policies rather than solely regional scrutiny. Out of the 127 identified criteria, the Business and Human Rights Resource Centre's toolkit incorporated 110, the most of the analyzed documents at 86 percent criteria fulfillment. Walmart Corporation's published transparency statement incorporated 22 criteria, representing the lowest inclusion at just over 17 percent. The following graphs provide further details, analysis, and ultimate conclusions. 
Criteria Included by Organization details the twenty organizations analyzed and their included criteria, broken into the three criteria categories: Internal Operations (Internal Criteria); External Operations (External Criteria); and Public Appearance/Publication (Publishing Criteria). The chart offers two dimensions for deeper analysis based on bar color and bar size. As shown, the Business Rights and Human Resource Centre's toolkit displays the darkest colors available in the graph as well as the widest bars, both indicating the large number of criteria fulfilled in the toolkit in comparison to the other analyzed publications.

This chart relays further detail into the compiled data's trends; the average total criteria included was 61 out of 127 total, or just over $48 \%$. Organizations appear most focused on internal operation requirements and guidelines with an average of 23.85 criteria included (out of 46), hovering close to 51 percent overall inclusion. The following most detailed category was Public Outreach/ Publication with an average inclusion of 20.55 criteria out of 41 , or nearly 50 percent of criteria fulfilled. The average relating to external operations, at just 41 percent inclusion (average of 16.6 criteria), exhibits the overall lack of focus on eradicating modern slavery in organization's external relationships, stake holding regions and overall peripheral operations. On a broad level, this analysis suggests that organizations are not taking as thorough, detailed precautions as might be expected based on the expansive layouts and grandiose goals of modern slavery publications

Criteria Included - Total Criteria

Criteria Included - Internal Criteria

Criteria Included - Internal Criteria

Criteria Included - Publication Criteria
Chart 2

Chart 3

Chart 4

Chart 5 
Drilled down, the analysis suggests some trends within individual organizations' statements. As expected, Business Rights and Human Resource Centre included the most criteria in each of the three categories. Walmart Corporation, likewise, was predictable in including the fewest criteria in two categories: internal operations and publication(s). However, Browne Jacobson was the organization including the fewest criteria in the external category, publishing only two criteria relating specifically to external relationships and operations. In understanding this breakdown, organizations can understand where their prevention and eradication efforts require the most improvement and how detailed other organizations' publications are, creating an opportunity from which to benchmark.

Organizations that were strong or weak in total criteria inclusion tended to remain on-trend when the analysis drilled down. Business Rights and Human Resource Centre, Burberry Group plc, Tesco PLC, Marks \& Spencer, and StrongerTogether proved among the most inclusive in all categories. These organizations provide premier, advanced, in-depth publications from which to guide other companies in either implementing or improving their own modern slavery prevention measures. If privy to more internal organization information, it would be interesting to know how successful these frameworks compare to companies with less inclusive publications or with no such preventative measures. The analysis suggests these organizations represent the most prepared to prevent and eradicate modern slavery, which may very well transfer to recognized success stories.

The above graphs also depict an important distinction in organizational focus on modern slavery prevention measures; there tends to be far more impressive emphasis on criteria relating to internal operations rather than organizations' published statements or criteria specific to external relationships. The analysis completed included a compilation of 46 internally-focused criteria stressed across frameworks and statements versus a close 41 and 40 criteria for the external and publication categories, respectively.

This, in combination with the highest average of included criteria, indicates the importance organizations place on taking responsibility within their most intimate operations, should they take responsibility at all, rather than spreading this importance over the entire organization's supply chain network. Of course, with limited resources there must be some sort of differentiating factor to determine where time and money are fixated; however, crimes of modern slavery are more likely to be perpetrated in downstream supply chain tiers wherein risks of modern slavery are most pronounced: "where 
workers have fewer protections through inadequate laws and regulations....and poor business and government accountability; where poverty levels are high amongst employees; "in conflict zones;" and in high-risk industries (typically involving raw materials) to name but a few ("Modern slavery in supply chains"). The countries with the most effective laws regarding modern slavery and organization transparency, the parent companies publishing these frameworks and statements; they are the least vulnerable in their organizational networks for modern slavery yet the most attention and prevention is directed to internal operations. This breakdown, then, poses an uncertainty as to the motivation for modern slavery prevention laws and subsequent publications. Are organizations publishing for the betterment of the organizational network by combatting modern slavery or publishing as a defense mechanism to protect the most central operations of the organization from poor representation in the press and to claim due diligence, whether these measures combat modern slavery effectively or not?

\section{Criteria Included by Organization} Table 7

Least Included Criteria by Organizations depicts the criteria included minimally within the twenty analyzed publications; 15 (11.8 percent) of the available criteria were included in three or fewer publications. Some of the criteria are included at such low rates due to verbiage differences, e.g. "require" versus "encourage," particularly for compliance with internal policies.

\section{Extended Analysis and Recommendation}

Though the efforts detailed above demonstrate investments in corrective actions by the business community regarding the private sector's role in modern slavery crimes, detailed analysis of twenty individual frameworks and statements published in the name of transparency and crime prevention shows the many points of risk yet to be recognized, let alone combatted. In order for these risks and vulnerabilities to be fully understood, and thus fully eradicated, the private sector must commit to a collective effort to publish modern slavery and transparency initiatives and take effective action against modern slavery within operations. If private sector players do not come together to address their roles in these crimes, the silent industry will remain just that: silent, hidden within global businesses, and taking cruel advantage of fellow men, women, 
and children.

The research and analysis detailed previously provide an instructive introduction for any private sector organization wanting to implement, expand or improve its modern slavery and transparency initiatives. The artificial division of criteria included within the utilized publications allows organizations to approach such implementations or improvements with specific focuses, such as looking to improve internal operational transparency.

\section{Total Organization Focus}

(Top five organizations for Percent of Total Criteria Included)

\begin{tabular}{|l|c|c|}
\hline \multicolumn{1}{|c|}{$\begin{array}{c}\text { Organization } \\
\text { Name }\end{array}$} & $\begin{array}{c}\text { Total Criteria } \\
\text { Included }\end{array}$ & $\begin{array}{c}\text { Percent of Total } \\
\text { Critera }\end{array}$ \\
\hline $\begin{array}{l}\text { Business and } \\
\text { Human Rights } \\
\text { Resource Centre } \\
\text { Burberry Plc }\end{array}$ & 110 & $87 \%$ \\
Tesco PLC & 90 & $71 \%$ \\
Stronger Together & 90 & $71 \%$ \\
Marks \& Spencer & 78 & $61 \%$ \\
\hline
\end{tabular}

The table Total Organization Focus outlines the five publications used in this paper containing the most detailed criteria and are therefore the most comprehensive examples of modern slavery publications through the lens of this analysis. Organizations looking to implement their first modern slavery and/ or transparency initiatives are recommended to begin with this table, using these recommendations as the bedrock of their own publications to ensure overall comprehensiveness and effectiveness based on industry standards.

\section{Internal Operations Focus}

(Top four organizations for Percent of Internal Criteria)

\begin{tabular}{|l|c|c|c|c|}
\hline \multicolumn{1}{|c|}{ Organization Name } & $\begin{array}{c}\text { Total Criteria } \\
\text { Included }\end{array}$ & $\begin{array}{c}\text { Percent of Total } \\
\text { Critera }\end{array}$ & $\begin{array}{c}\text { Internal Criteria } \\
\text { Included }\end{array}$ & $\begin{array}{c}\text { Percent of Internal } \\
\text { Criteria }\end{array}$ \\
\hline $\begin{array}{l}\text { Business and Human Rights } \\
\text { Resource Centre }\end{array}$ & 110 & $87 \%$ & 43 & $93 \%$ \\
\hline Burberry Group Plc. & 90 & $71 \%$ & 41 & $89 \%$ \\
\hline Tesco PLC & 90 & $71 \%$ & 36 & $78 \%$ \\
\hline Oxford Brookes University & 73 & $57 \%$ & 33 & $72 \%$ \\
\hline
\end{tabular}




\section{External Operations Focus}

\begin{tabular}{|l|c|c|c|c|}
\multicolumn{5}{c}{ (Top four organizations for Percent of External Criteria) } \\
\hline \multicolumn{1}{|c|}{ Organization Name } & $\begin{array}{c}\text { Total Criteria } \\
\text { Included }\end{array}$ & $\begin{array}{c}\text { Percent of Total } \\
\text { Critera }\end{array}$ & $\begin{array}{c}\text { External Criteria } \\
\text { Included }\end{array}$ & $\begin{array}{c}\text { Percent of External } \\
\text { Criteria }\end{array}$ \\
\hline $\begin{array}{l}\text { Business and Human Rights } \\
\text { Resource Centre }\end{array}$ & 110 & $87 \%$ & 31 & $78 \%$ \\
Burberry Group Plc. & 90 & $71 \%$ & 25 & $63 \%$ \\
Marks \& Spencer & 78 & $61 \%$ & 24 & $60 \%$ \\
Tesco PLC & 90 & $71 \%$ & 23 & $58 \%$ \\
\hline
\end{tabular}

\section{Public Appearance (CSR) Focus}

(Top four organizations for Percent of Publication Criteria)

\begin{tabular}{|l|c|c|c|c|}
\hline \multicolumn{1}{|c|}{ Organization Name } & $\begin{array}{c}\text { Total Criteria } \\
\text { Included }\end{array}$ & $\begin{array}{c}\text { Percent of Total } \\
\text { Critera }\end{array}$ & $\begin{array}{c}\text { Publication Criteria } \\
\text { Included }\end{array}$ & $\begin{array}{c}\text { Percent of } \\
\text { Publication Criteria }\end{array}$ \\
\hline $\begin{array}{l}\text { Business and Human Rights } \\
\text { Resource Centre }\end{array}$ & 110 & $87 \%$ & 38 & $93 \%$ \\
Tesco PLC & 90 & $71 \%$ & 31 & $78 \%$ \\
Marks \& Spencer & 78 & $61 \%$ & 28 & $70 \%$ \\
Stronger Together & 78 & $61 \%$ & 26 & $65 \%$ \\
\hline
\end{tabular}

Public Appearance (CSR) Focus

(Top four organizations for Percent of Publication Criteria)

\begin{tabular}{|l|c|c|c|c|}
\hline \multicolumn{1}{|c|}{ Organization Name } & $\begin{array}{c}\text { Total Criteria } \\
\text { Included }\end{array}$ & $\begin{array}{c}\text { Percent of Total } \\
\text { Critera }\end{array}$ & $\begin{array}{c}\text { Publication Criteria } \\
\text { Included }\end{array}$ & $\begin{array}{c}\text { Percent of } \\
\text { Publication Criteria }\end{array}$ \\
\hline \begin{tabular}{l|c|c|c|} 
Business and Human Rights \\
Resource Centre
\end{tabular} & 110 & $87 \%$ & 38 & $93 \%$ \\
Tesco PLC & 90 & $71 \%$ & 31 & $78 \%$ \\
Marks \& Spencer & 78 & $61 \%$ & 28 & $70 \%$ \\
Stronger Together & 78 & $61 \%$ & 26 & $65 \%$ \\
\hline
\end{tabular}


The data in the Internal Operations Focus, External Operations Focus, and Public Appearance (CSR) Focus tables mimic the recommendation process outlined in the Total Organization Focus table, yet are further drilled down to recommend publications specifically for organizations wanting to improve or expand their initiatives with specific concentrations. Each table provides recommendations of the four most inclusive publications per criteria, based on previous analysis, again serving as a foundation for organizations looking to improve these specific emphases.

The criteria detailed within these publications is the realized substance behind this analysis. Organizations including the most and broadest scope of detail yet lacking vital actionable emphases prove the need for publications being entirely comprehensive to be effective. Trends in criteria inclusion or lack thereof provide important insights into private sector risks and vulnerabilities being addressed (in)effectively; the criteria not being included, unfortunately, corresponds to the areas of highest susceptibility in global supply chains.

\section{Top Included Criteria}

( $80 \%$ and above for Percent of Organizations Utilizing Criteria)

\begin{tabular}{|c|c|c|}
\hline Criteria & $\begin{array}{c}\text { Percent of } \\
\text { Organizations } \\
\text { Utilizing Criteria }\end{array}$ & $\begin{array}{l}\text { Percent of Total } \\
\text { Criteria Count }\end{array}$ \\
\hline Implement internal training programs & $85 \%$ & $13.4 \%$ \\
\hline $\begin{array}{l}\text { Conduct internal risk assessment to identify actual and potential modern slavery threats and } \\
\text { risks }\end{array}$ & $85 \%$ & $13.4 \%$ \\
\hline Require corporate/board support and commitment & $80 \%$ & $12.6 \%$ \\
\hline Emphasize human rights due diligence & $80 \%$ & $12.6 \%$ \\
\hline Develop in-house, specific initiatives/policies & $80 \%$ & $12.6 \%$ \\
\hline Collaborate due diligence efforts and information & $80 \%$ & $12.6 \%$ \\
\hline Monitor suppliers on human rights and modern slavery risks & $80 \%$ & $12.6 \%$ \\
\hline $\begin{array}{l}\text { Conduct external risk assessment to identify actual and potential modern slavery threats and } \\
\text { risks }\end{array}$ & $80 \%$ & $12.6 \%$ \\
\hline Require corporate/board support and commitment & $80 \%$ & $12.6 \%$ \\
\hline Include citation of national and/or global framework & $80 \%$ & $12.6 \%$ \\
\hline
\end{tabular}


Lowest Included Criteria

( $15 \%$ and below for Percent of Organizations Utilizing Criteria)

\begin{tabular}{|c|c|c|}
\hline Criteria & $\begin{array}{c}\text { Percent of } \\
\text { Organizations } \\
\text { Utilizing Criteria }\end{array}$ & $\begin{array}{c}\text { Percent of Total } \\
\text { Criteria Count }\end{array}$ \\
\hline Number of employees trained in modern slavery & $15 \%$ & $2.4 \%$ \\
\hline Require full reporting and disclosure on modern slavery initiatives and results & $15 \%$ & $2.4 \%$ \\
\hline Encourage action plans regarding bottom tiers of partner supply chains & $15 \%$ & $2.4 \%$ \\
\hline Encourage compliance with Organization Code of Conduct & $15 \%$ & $2.4 \%$ \\
\hline Include an Organization Partner Non-Compliance Policy & $15 \%$ & $2.4 \%$ \\
\hline Include results of supplier and supply chain monitoring & $15 \%$ & $2.4 \%$ \\
\hline Reference UN Global Compact/ Sustainable Development Goals & $15 \%$ & $2.4 \%$ \\
\hline Require internal stakeholder compliance & $10 \%$ & $1.6 \%$ \\
\hline Encourage compliance with Organization Human Rights Policy & $10 \%$ & $1.6 \%$ \\
\hline $\begin{array}{l}\text { Require suppliers to explain how their human rights policies are implemented within their } \\
\text { supply chains }\end{array}$ & $10 \%$ & $1.6 \%$ \\
\hline Reference pending Australian Modern Slavery Bill & $10 \%$ & $1.6 \%$ \\
\hline Require internal stakeholder compliance & $5 \%$ & $0.8 \%$ \\
\hline Number of contracts including modern slavery provisions & $5 \%$ & $0.8 \%$ \\
\hline Encourage compliance with Organization Partner Non-Compliance Policy & $5 \%$ & $0.8 \%$ \\
\hline Encourage compliance with Organization Migrant Worker Policy & $5 \%$ & $0.8 \%$ \\
\hline Require compliance with Organization Migrant Worker Policy & $5 \%$ & $0.8 \%$ \\
\hline $\begin{array}{l}\text { Require suppliers to cascade organization modern slavery standards/obligations throughout } \\
\text { supply chain tiers }\end{array}$ & $5 \%$ & $0.8 \%$ \\
\hline $\begin{array}{l}\text { Encourage suppliers to implement corrective action plans for their non-compliant } \\
\text { stakeholders }\end{array}$ & $5 \%$ & $0.8 \%$ \\
\hline Require suppliers to publish modern slavery statements and/or evidence of due diligence & $5 \%$ & $0.8 \%$ \\
\hline
\end{tabular}

The Top Included Criteria recommendation table outlines criteria included by 80 percent or more of the analyzed publications. These recommendations provide a check for organizations to ensure requirements included by the majority of peers are also included or added to their initiatives.

The Lowest Criteria Included table offers recommendations for organizations to view requirements that are being ignored by the majority of peers, offering an opportunity to build more comprehensive, effective initiatives through their incorporation. Strikingly, as depicted between the Lowest Criteria Included recommendation table and the Least Criteria Included by Organization table, less than 15 percent of analyzed publications contained information addressing, in particular: cascading modern slavery initiatives throughout supply chain tiers; publishing results of supply chain monitoring; 
requiring or encouraging internal Human Rights and/or Fair Labor policies; and implementing corrective action plans for noncompliant stakeholders. Perhaps most detrimental is the lack of dedication to addressing modern slavery in lower supply chain tiers, as though organizations are oblivious to the data showing upstream supply chain practices harbor the most significant risk for modern slavery crimes ("Modern Slavery"). In their modern slavery research, authors Katherine Leanne Chris and Roger Leonard Burrit address this omittance:

"LeBaron... reports that only one third of companies seek transparency in relation to labour practices below their Tier 1 suppliers... This is problematic as it is upstream in the supply chain that most labour abuses in business tend to occur... this practice ignores and/or overlooks the problem of contract workers, often engaged via intermediaries or agents, and those employed in "shadow factories" who are among the most vulnerable people in global production networks" (Christ).

A study conducted by Verisk Maplecroft supports Chris' and Burrit's concerns: "although many companies perform due diligence to prevent slavery and corruption among Tier 1 suppliers, the real risk lies in lower tier suppliers upstream. Corporations need to do more to implement policies that reach even the lowest tier of suppliers...," whether it be incorporating lower tiers into current modern slavery initiatives or creating entirely new programs to address risks that are farther removed from everyday operations, yet are just as entwined with the parent entity ("Danger of the Unknown: Asian Supply Chains at High Risk for Corruption and Slavery"). Some organizations include references to possible threats in upstream supply chain entities, acknowledging comprehension of the underlying problem, yet do not specifically address these threats in published statements.

The key pieces of legislation adopted addressing modern slavery, most specifically the CSCTA and UKMSA, likewise do not include specific requirements for eradication or even reporting efforts regarding Tier 2 and beyond supply chain agents. Whether omitted due to oversight, limited prevention resources, because required inclusion of lower tier partner interaction is not incorporated in modern slavery legislation, or further reasons, it is clear this is a vital piece of eradicating modern slavery that is being ignored by the organizations claiming to be the most proactive.

Another hindrance in fighting global slavery, apparent from this analysis, is the monetary power inherent in accessing modern slavery resources. Of the 20 organizations used in this analysis, two could be categorized as charitable/ non- 
profit organizations; two as membership societies; one as a public university; and one as a governmental department. The remaining fourteen were categorized as for-profit companies/ business entities or a corporate initiative. Though all publications analyzed were available as free, accessible information, this disparity matches the resources available for the private sector entities wanting to improve, expand or implement modern slavery and transparency initiatives. The for-profit entities producing these publications research and report on their own operations and possibly their industry's; resources are not dedicated to widespread prevention or information dissemination. Private sector entities have been depicted as more likely to produce free resources, yet such resources are the least universal for outside use. Non-profits and public universities rely on far fewer resources overall; most charitable resources found during research were not accessible freely. Of the resources found requiring purchase, the majority were available as consulting tools for multinational corporate entities. There are significant resources, therefore, available to large private sector entities for guidance in implementing modern slavery measures; fewer, however, are available with universal information to poorer organizations. Though important to target efforts at eradicating modern slavery in mammoth multinational supply chains, it is imperative this global crime be addressed universally; modern slavery can appear in any business form.

This analysis also provides a starting comparison amongst global slavery legislation. Boasting 65 percent of the included organizations and nearly 79 percent of identified criteria, the United Kingdom's Modern Slavery Act appears the most comprehensive and effective at forcing organizational action. Legislation from the United States proved too broad in requirements, comparatively; at 38 average included criteria it is evident the United States' private sector and government must do more to become tangibly effective. Most telling about global legislation, however, comes from the collective criteria analyzed: there is no true mandate for effective action from organizations against these crimes; at most, reporting on actions taken - whether effective or not - is the only legal obligation (Idris). The United States and other nations would do well to follow the precedent of the UKMSA, but by no means are any of these legislative initiatives comprehensive.

Per the results of this extended analysis, any organizations looking to begin or further the process of investing in modern slavery and transparency initiatives should begin with the toolkit available from the Business and Human Rights Resource Center. By far the most comprehensive, this publication is supported by strong research and comparative analysis to provide 
organizations with myriad views of modern slavery crimes, the successes and failures of other organizations and governments attempting to combat these crimes, and suggestions based on critical analysis for how to best address this global crisis. Any private sector organization, whether implementing entirely new initiatives or expanding or improving current ones, should also utilize the recommendation tables for both publications and criteria. Together these recommendations provide a valuable foundation for expanding the implementation of these initiatives for global businesses and will hopefully play some small role in the disentanglement of private business from modern slavery, and ultimately the eradication of the silent industry from business altogether. 


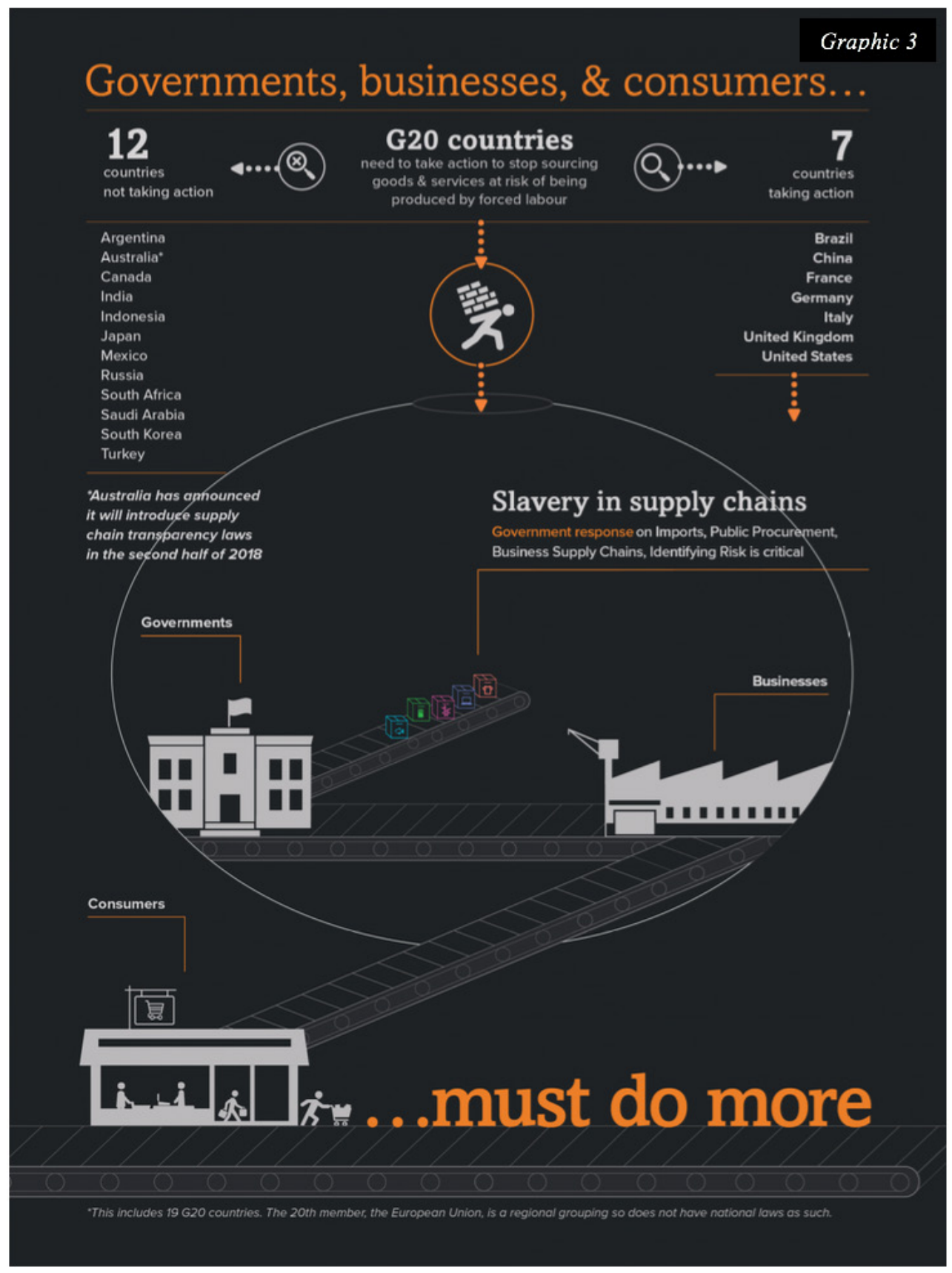

\section{Conclusion}

The butterfly effect, originating from chaos theory, describes "how small changes to a seemingly unrelated thing or condition... can affect large, complex systems" ("The Supply-Chain Butterfly Effect”). Unbeknownst to the system 
driver, outwardly unconnected actions can come together to disrupt the overarching system. Though not a perfect metaphor, the butterfly effect has its place in global supply chains: the actions of a supply chain member, regardless of how removed, can pose detrimental consequences to the entire operation.

Operating under the highest level of legal requirements to mitigate business disruptions and protect operational integrity is a noble but assumed role of corporations; amending those practices to embrace fiduciary duty and create a global supply chain operating with the highest standard of care for all stakeholders could produce surprising rewards that are only just being realized for transnational companies. Operating within good ethical standards, embracing corporate social responsibility actions and going beyond compliance requirements to work toward eradicating modern slavery crimes are all difficult positions for companies to fully commit to without receiving backlash or undergoing relentless scrutiny. However, the difficulties are met with benefits: companies are likely to increase profits and social acceptance, build brand recognition, and much more from adopting proactive approaches to such global calamities. Truly, the greatest risk for companies engaging in modern slavery efforts is the risk of inaction; a global crisis spurred by private sector operations, adopting and implementing modern slavery measures benefits public, private, and imprisoned stakeholders yearning for their freedom. 


\section{REFERENCES}

Are You Ready for the Modern Slavery Act 2015? Guidance." BrowneJacobson, 5 Nov. 2015, https://www.brownejacobson.com/-/media/Files/PDFDocuments/4/Are-you-ready-for-the-Moder-Slavery-Act-2015---Guidance. ashx?la=en Accessed 2 Feb. 2019.

Borelli, Tom. "Unilever and the Failure of Corporate Social Responsibility." Forbes, 15 May 2017,www.forbes.com/sites/e.conostats/2017/03/15/unileverand-the-failure-of-corporate-social-responsibility/\#40ae5356498d. Accessed 20 Sep. 2018.

"California Transparency in Supply Chains Act." Walmart, Jun. 2017. corporate.walmart.com/california-transparency. Accessed 22 Jan.2019.

Carroll, Archie B. "A History of Corporate Social Responsibility: Concepts and Practices." The Oxford Handbook of Corporate Social Responsibility, pp. 19-46. Oxford UP, 2008, www.researchgate.net/ publication/282746355_A_History_of_Corp orate_Social_Responsibility_ Concepts_and_Practices. Accessed 8 Apr. 2019.

Chong, Kelsey. "Millennials and the Rising Demand for Corporate Social Responsibility." California Review Management, University of California, Berkley, 20 Jan. 2017, cmr.berkeley.edu/blog/2017/1/millennials-and-csr/. Accessed 10 Nov. 2018.

Christ, Katherine Leanne, and Roger Leonard Burritt. "Current perceptions on the problem of modern slavery in business." Business Strategy \& Development, vol. 1, no. 2, Wiley Online Library, 12 Feb. 2018, onlinelibrary. wiley.com/doi/full/10.1002/bsd2.15. Accessed 28 Feb. 2019.

"Danger of the Unknown: Asian Supply Chains at High Risk for Corruption and Slavery." Source Intelligence, www.sourceintelligence.com/dangerunknown-asian-supply-chains-high-risk-corruption-slavery. Accessed 28 Feb. 2019. 
“ECCO Modern Slavery Statement 2017." ECCO. 2017, media.ecco.com/ GroupCommunication/Modern_Slavery_Statemen t/?page=1. Accessed 24 Jan. 2019.

Epstein-Reeves, James. "Consumers Overwhelmingly Want CSR." Forbes, 15 Dec. 2010, www.forbes.com/sites/csr/2010/12/15/new-study-consumers-demandcompanies-implement-csr-programs/\#359b3ba765c7. Accessed 15 Nov. 2018.

European Coalition for Corporate Justice. "French Corporate Duty of Vigilance Law: Frequently Asked Questions." Corporate Justice, corporatejustice.org/ documents/publications/french- corporate-duty-of-vigilance-law-faq.pdf. Accessed 15 Sep. 2018.

"FTSE 100 \& the UK Modern Slavery Act: From Disclosure to Action." Business and Human Rights Resource Centre, 2018, www.business-humanrights. org/en/ftse-100-the-uk-modern-slavery-act-from-disclosure-to-action. Accessed 24 Jan. 2019.

"Global Estimates of Modern Slavery: Forced Labour and Forced Marriage." International Labour Office (ILO), Geneva, 2017, www.ilo.org/wcmsp5/groups/ public/---dgreports/---dcomm/documents/publication/wcms_575479.pdf. Accessed 5 Oct. 2018.

International Labour Office, International Organization for Migration and Walk Free Foundation. Global Estimates of Modern Slavery: Forced Labour and Forced Marriage. ILO Publications, 2017. www.ilo.org/global/publications/ books/WCMS_575479/lang--en/index.htm. Accessed 3 Oct. 2018.

Lynn, Matthew. "Corporate Social Responsibility has become a racket - and a dangerous one." The Telegraph, 28 Sep. 2015, www.telegraph.co.uk/finance/ newsbysector/industry/11896546/Corporate-Social-Responsibility-hasbecome-a-racket-and-a-dangerous-one.html. Accessed 15 Nov. 2018.

MacCarthy, Libby. "New Report reveals $86 \%$ of US Consumers Expect Companies to Act on Social, Environmental Issues." Sustainable Brands, 18 May 2017, sustainablebrands.com/read/marketing-andcomms/new-report-reveals-86-of-us-consumers-expect-companies-to-acton-social-environmental-issues. Accessed 23 Sep. 2018. 
McPherson, Susan. "6 CSR Trends To Watch In 2017." Forbes, 19 Jan. 2017, www. forbes.com/sites/susanmcpherson/2017/01/19/6-csr-trends-to-watch-in2017/\#4f324602blcc. Accessed 20 Nov. 2018.

"Modern Slavery." Ethical Trading Initiative, www.ethicaltrade.org/issues/ modern-slavery. Accessed 25 Feb. 2019.

"Modern Slavery Act 2015 and Transparency in Supply Chains Act of 2010 Burberry Group plc Statement." Burberry, 9 May 2018, www.burberryplc. com/en/site-services/transparency-in-the-supply-chain-and-modernslavery-statement.html. Accessed 29 Jan. 2019.

“Modern Slavery and Human Trafficking Statement." Unilever, 25 Jan. 2017. www.unilever.com/Images/unilever-slavery-and-human-traffickingstatement-2017_tcm244-498073_en.pdf. Accessed 21 Jan. 2019.

"Modern slavery in supply chains." Chartered Institute of Procurement \& Supply, www.cips.org/Documents/About\%20CIPS/Ethics/3/CIPS_Modern Slavery_Broch_WEB.pdf. Accessed 3 Feb. 2019.

"Modern Slavery in Supply Chains Reporting Requirement." KPMG, Oct. 2017, newsroom.kpmg.com.au/wp-content/uploads/2017/10/AGSubmission-Modern-Slavery-in-Supply-Chains-Reporting-RequirementFINAL-20.10.2017.pdf. Accessed 1 Feb. 2019.

“Modern Slavery Statement 2017/18." Tesco, 10 May 2018, www.tescoplc.com/ media/392433/modern_slavery_act.pdf. Accessed 1 Feb. 2019.

"Modern Slavery: Our Statement on Slavery and Human Trafficking 2018." Nationa/ Grid, 2018, www.nationalgrid.com/sites/default/files/ documents/14842_NG_Modern_Slavery_A4_AWO8_INT1\%20\%281\%29.pdf. Accessed 25 Jan. 2019.

"Modern Slavery Toolkit: A Guide and Resources to Ensure your Co-Op Tackles Modern Slavery." Co-Operatives UK, 7 Jun. 2017, www.uk.coop/ resources/modern-slavery. Accessed 28 Jan. 2019. 
"Modern Slavery Toolkit for Suppliers and Partners." Marks \& Spencer, 28 Feb. 2017, corporate.marksandspencer.com/plan-a/reports-andpublications. Accessed 20 Jan. 2019.

Needle, Peter. "The Global Spread of Modern Slavery Act Legislation." Segura, 2 Aug. 2016, www.segura.co.uk/newsroom/the-global-spread-modern-slaveryact-legislation. Accessed 10 Feb. 2019.

New South Wales Government. Modern Slavery Act 2018 No 30. New South Wales Legis/ation, 8 Jan. 2019, www.legislation.nsw.gov.au/\#/view/ act/2018/30. Accessed 20 Jan. 2018.

Ochab, Ewelina U. "Human Trafficking is a Pandemic of the 21st Century." Forbes, 26 Jul. 2018, www.forbes.com/sites/ewelinaochab/2018/07/26/ human-trafficking-is-a-pandemic-of-the-21st-century/\#17a86ddd6195. Accessed 23 Sep. 2018.

"Our Strategy." The Mekong Club, 2017, themekongclub.org/our-strategy/. Accessed 3 Oct. 2018.

"Recommended for a Modern Slavery Statement." Corporate Responsibility, Jun. 2017, corporate-responsibility.org/wp-content/uploads/2017/06/Core_ RecommendedcontentFINAL1.pdf. Accessed 20 Jan. 2019.

"Resource and Action Guide for Apparel \& Footwear Companies." KnowTheChain, May 2017, knowthechain.org/wp-content/uploads/KTC_AF_ ActionGuide_Letter_Final_Web.pdf. Accessed 12 Oct. 2018.

"Slavery and Human Trafficking Statement for the financial year ended 31 March 2016." Business-Human Rights, 31 Mar. 2016, www.business-humanrights. org/sites/default/files/SABMiller\%20Slavery\%2Oand\%2OHuman\%20 Trafficking\%2Ostatement\%2OFINAL\%202016_O.pdf. Accessed 24 Jan. 2019.

"Stop Slavery Hotel Industry Network." Shiva Foundation, 2018, www. shivafoundation.org.uk/industry-network. Accessed 25 Jan. 2019.

"Tackling Modern Slavery in Global Supply Chains Toolkit." Stronger Together, Oct. 2017, www.stronger2gether.org/product/toolkit-for-global-supplychains. Accessed 24 Jan. 2019. 
The Parliament of the United Kingdom. Modern Slavery Act 2015, c. 30. Gov.uk, www.legislation.gov.uk/ukpga/2015/30/contents/enacted. Accessed $15 \mathrm{Sep}$. 2018.

"The Issue." Know the Chain, 2019, knowthechain.org/the-issue/. Accessed 5 Oct. 2018.

"The Supply-Chain Butterfly Effect." Datamaran, www.datamaran.com/thesupply-chain-butterfly-effect. Accessed 1 Mar. 2019.

“Toolkit Material." Oxford Brookes University, 2019, www.brookes. ac.uk/microsites/combat-human-trafficking/the-toolkit/toolkitmaterial/?langtype=2057. Accessed 21 Jan. 2019.

"Understand." Walk Free Foundation, www.walkfreefoundation.org/ understand/. Accessed 30 Sep. 2018.

United Nations Office on Drugs and Crime, Toolkit to Combat Trafficking in Persons: Global Programme Against Trafficking in Human Beings. United Nations, 2006, www.unodc.org/documents/human-trafficking/HT_ ToolkitO8_English.pdf). Accessed 20 Jan. 2019.

"2017 Statement on Efforts to Combat Human Trafficking and Slavery in Our Business and Supply Chains." Apple, 28 Feb. 2018, images.apple.com/ supplier-responsibility/pdf/Apple-Combat-Human-Trafficking-and-Slaveryin-Supply-Chain.pdf. Accessed 1 Feb. 2019. “

2018 Global Slavery Index." Walk Free Foundation, 2018, www. globalslaveryindex.org/. Accessed 2 Oct. 2018.

"2018 Global Slavery Index Highlights." Walk Free Foundation, 2018, www. globalslaveryindex.org/2018/findings/highlights/. Accessed 2 Oct. 2018. 


\section{APENDEX}

\section{Apendex 2}

Lowest Internal Criteria

(15\% and below for Percent of Organizations Utilizing Criteria)

\begin{tabular}{|c|c|c|}
\hline Criteria & $\begin{array}{c}\text { Percent of } \\
\text { Organizations } \\
\text { Utilizing Criteria }\end{array}$ & $\begin{array}{c}\text { Percent of Total } \\
\text { Internal Criteria } \\
\text { Count }\end{array}$ \\
\hline $\begin{array}{l}\text { Publish an Organization Human Rights/ Anti-MS\&HT Policy and require internal stakeholder } \\
\text { compliance }\end{array}$ & $15 \%$ & $7 \%$ \\
\hline Require internal stakeholder compliance & $10 \%$ & $4 \%$ \\
\hline Number of contracts including modern slavery provisions & $5 \%$ & $2 \%$ \\
\hline
\end{tabular}

Top External Criteria

( $80 \%$ and above for Percent of Organizations Utilizing Criteria)

\begin{tabular}{|l|c|c|}
\hline \multicolumn{1}{|c|}{ Criteria } & $\begin{array}{c}\text { Percent of } \\
\text { Organizations } \\
\text { Utilizing Criteria }\end{array}$ & $\begin{array}{c}\text { Percent of Total } \\
\text { Internal Criteria } \\
\text { Count }\end{array}$ \\
\hline $\begin{array}{l}\text { Conduct external risk assessment to identify actual and potential modern slavery threats and } \\
\text { risks }\end{array}$ & $95 \%$ & $48 \%$ \\
Collaborate due diligence efforts and information & $90 \%$ & $45 \%$ \\
$\begin{array}{l}\text { Direct engagement with key stakeholders regarding due diligence efforts } \\
\text { Monitor suppliers on human rights and modern slavery risks }\end{array}$ & $90 \%$ & $45 \%$ \\
Collaborate with supply chain members & $90 \%$ & $45 \%$ \\
$\begin{array}{l}\text { Direct engagement with supply chain partners } \\
\text { Require external stakeholders' compliance with modern slavery eradication efforts }\end{array}$ & $85 \%$ & $43 \%$ \\
\hline
\end{tabular}

\section{Top Internal Criteria}

( $80 \%$ and above for Percent of Organizations Utilizing Criteria)

\begin{tabular}{|l|c|c|}
\hline \multicolumn{1}{|c|}{ Criteria } & $\begin{array}{c}\text { Percent of } \\
\text { Organizations } \\
\text { Utilizing Criteria }\end{array}$ & $\begin{array}{c}\text { Percent of Total } \\
\text { Internal Criteria } \\
\text { Count }\end{array}$ \\
\hline $\begin{array}{l}\text { Implement internal training programs } \\
\text { Conduct internal risk assessment to identify actual and potential modern slavery threats and } \\
\text { risks }\end{array}$ & $100 \%$ & $43 \%$ \\
Require corporate/board support and commitment & $100 \%$ & $43 \%$ \\
$\begin{array}{l}\text { Emphasize human rights due diligence } \\
\text { Develop in-house, specific initiatives/policies }\end{array}$ & $95 \%$ & $41 \%$ \\
Emphasize high-risk locations/commodities/suppliers & $95 \%$ & $41 \%$ \\
\hline $\begin{array}{l}\text { Executive officer signs and approves modern slavery statements } \\
\text { Publish an ethical Organization/Supplier Code of Conduct } \\
\text { Publish an Organization Responsible Sourcing/ Procurement Policy }\end{array}$ & $95 \%$ & $41 \%$ \\
\hline
\end{tabular}




\section{Top Public Appearance (CSR) Criteria}

( $80 \%$ and above for Percent of Organizations Utilizing Criteria)

\begin{tabular}{|l|c|c|}
\hline \multicolumn{1}{|c|}{ Criteria } & $\begin{array}{c}\text { Percent of } \\
\text { Organizations } \\
\text { Utilizing Criteria }\end{array}$ & $\begin{array}{c}\text { Percent of Total } \\
\text { Cublishing } \\
\text { Criteria Count }\end{array}$ \\
\hline Require corporate/board support and commitment & $95 \%$ & $46 \%$ \\
Include citation of national and/or global framework & $95 \%$ & $46 \%$ \\
Report policies/intiatives regarding modern slavery & $90 \%$ & $44 \%$ \\
Reference UK Modern Slavery Act 2015 & $90 \%$ & $44 \%$ \\
Organization's supply chain partners/structure /locations & $85 \%$ & $41 \%$ \\
Publish statement(s) on organization public platform & $80 \%$ & $39 \%$ \\
Require signature of corporate/board member & $80 \%$ & $39 \%$ \\
Clear title of policy/statement & $80 \%$ & $39 \%$ \\
\hline
\end{tabular}

\section{Lowest Public Appearance (CSR) Criteria}

(15\% and below for Percent of Organizations Utilizing Criteria)

\begin{tabular}{|l|c|c|}
\hline \multicolumn{1}{|c|}{ Criteria } & $\begin{array}{c}\text { Percent of } \\
\text { Organizations } \\
\text { Utilizing Criteria }\end{array}$ & $\begin{array}{c}\text { Percent of Total } \\
\text { Criteria Count }\end{array}$ \\
\hline Include results of supplier and supply chain monitoring & $15 \%$ & $7 \%$ \\
Reference UN Global Compact/ Sustainable Development Goals & $15 \%$ & $7 \%$ \\
Reference pending Australian Modern Slavery Bill & $10 \%$ & $2 \%$ \\
\hline
\end{tabular}

\section{Lowest External Criteria}

( $15 \%$ and below for Percent of Organizations Utilizing Criteria)

\begin{tabular}{|l|c|c|}
\hline \multicolumn{1}{|c|}{ Criteria } & $\begin{array}{c}\text { Percent of } \\
\text { Organizations } \\
\text { Utilizing Criteria }\end{array}$ & $\begin{array}{c}\text { Percent of Total } \\
\text { External Criteria } \\
\text { Count }\end{array}$ \\
\hline $\begin{array}{l}\text { Require suppliers to explain how their human rights policies are implemented within their } \\
\text { supply chains }\end{array}$ & $15 \%$ & $8 \%$ \\
$\begin{array}{l}\text { Encourage compliance with Organization Human Rights Policy } \\
\text { Require compliance with Organization Migrant Worker Policy } \\
\text { Require suppliers to cascade organization modern slavery standards/obligations throughout } \\
\text { supply chain tiers }\end{array}$ & $10 \%$ & $5 \%$ \\
$\begin{array}{l}\text { Encourage compliance with Organization Partner Non-Compliance Policy } \\
\text { Encourage compliance with Organization Migrant Worker Policy } \\
\text { Encourage suppliers to implement corrective action plans for their non-compliant } \\
\text { stakeholders }\end{array}$ & $10 \%$ & $5 \%$ \\
Require suppliers to publish modern slavery statements and/or evidence of due diligence & $5 \%$ & $3 \%$ \\
\hline
\end{tabular}

